\title{
Communication
}

\section{Superior Non-Invasive Glucose Sensor Using Bimetallic CuNi Nanospecies Coated Mesoporous Carbon}

\author{
Ahmed Bahgat Radwan 1,*(D), Sreedevi Paramparambath ${ }^{1}$, John-John Cabibihan ${ }^{2}{ }^{\circledR}$, Abdulaziz Khalid Al-Ali ${ }^{3,4}{ }^{(\mathbb{C}}$, \\ Peter Kasak ${ }^{1}\left(\mathbb{D}\right.$, Rana A. Shakoor ${ }^{1}\left(\mathbb{D}\right.$, Rayaz A. Malik ${ }^{5}$, Said A. Mansour ${ }^{6}$ and Kishor Kumar Sadasivuni ${ }^{1, *}{ }^{1}$ \\ 1 Center for Advanced Materials (CAM), Qatar University, Doha P.O. Box 2713, Qatar; \\ sreedevisathyan96@gmail.com (S.P.); peter.kasak@qu.edu.qa (P.K.); shakoor@qu.edu.qa (R.A.S.) \\ 2 Department of Mechanical and Industrial Engineering, Qatar University, Doha P.O. Box 2713, Qatar; \\ john.cabibihan@qu.edu.qa \\ 3 Department of Computer Engineering, Qatar University, Doha P.O. Box 2713, Qatar; a.alali@qu.edu.qa \\ 4 KINDI Center for Computing Research, Qatar University, Doha, P.O. Box 2713, Qatar \\ 5 Weill Cornell Medicine-Qatar, Qatar Foundation-Education City, Doha P.O. Box 24144, Qatar; \\ ram2045@qatarmed.cornell.edu \\ 6 Qatar Energy and Environment Research Institute, Hamad bin Khalifa University, Qatar Foundation, \\ Doha P.O. Box 34110, Qatar; smansour@hbku.edu.qa \\ * Correspondence: ahmedbahgat@qu.edu.qa (A.B.R.); kishorkumars@qu.edu.qa (K.K.S.)
}

Citation: Radwan, A.B.

Paramparambath, S.; Cabibihan, J.-J.; Al-Ali, A.K.; Kasak, P.; Shakoor, R.A.; Malik, R.A.; Mansour, S.A.; Sadasivuni, K.K. Superior Non-Invasive Glucose Sensor Using Bimetallic CuNi Nanospecies Coated Mesoporous Carbon. Biosensors 2021, 11, 463. https://doi.org/10.3390/ bios11110463

Received: 30 September 2021

Accepted: 12 November 2021

Published: 18 November 2021

Publisher's Note: MDPI stays neutral with regard to jurisdictional claims in published maps and institutional affiliations.

Copyright: (c) 2021 by the authors. Licensee MDPI, Basel, Switzerland. This article is an open access article distributed under the terms and conditions of the Creative Commons Attribution (CC BY) license (https:// creativecommons.org/licenses/by/ $4.0 /)$.

\begin{abstract}
The assessment of blood glucose levels is necessary for the diagnosis and management of diabetes. The accurate quantification of serum or plasma glucose relies on enzymatic and nonenzymatic methods utilizing electrochemical biosensors. Current research efforts are focused on enhancing the non-invasive detection of glucose in sweat with accuracy, high sensitivity, and stability. In this work, nanostructured mesoporous carbon coupled with glucose oxidase $\left(\mathrm{GO}_{\mathrm{x}}\right)$ increased the direct electron transfer to the electrode surface. A mixed alloy of $\mathrm{CuNi}$ nanoparticle-coated mesoporous carbon (CuNi-MC) was synthesized using a hydrothermal process followed by annealing at $700{ }^{\circ} \mathrm{C}$ under the flow of argon gas. The prepared catalyst's crystal structure and morphology were explored using $X$-ray diffraction and high-resolution transmission electron microscopy. The electrocatalytic activity of the as-prepared catalyst was investigated using cyclic voltammetry (CV) and amperometry. The findings show an excellent response time of $4 \mathrm{~s}$ and linear range detection from 0.005 to $0.45 \mathrm{mM}$ with a high electrode sensitivity of $11.7 \pm 0.061 \mathrm{~mA} \mathrm{mM} \mathrm{cm}{ }^{-2}$ in a selective medium.
\end{abstract}

Keywords: sweat sensor; glucose detection; non-invasive; mesoporous carbon; bimetallic nanomaterials

\section{Introduction}

The accurate quantification of glucose is key to the diagnosis and management of patients with diabetes. In 2019, the International Diabetes Federation estimated that diabetes affects 463 million people, constituting $9.3 \%$ of the adult population aged $20-79$, but with 1 in 2 remaining undiagnosed. Chronic hyperglycemia is a major risk parameter for long-term microvascular and macrovascular complications leading to increased morbidity and mortality, with $11.3 \%$ of global deaths being attributed to diabetes [1,2]. Additionally, in patients with COVID-19, whilst long-term glycemic control has not been associated with adverse outcomes, the severity of hyperglycemia at admission has been allied to the prerequisite for mechanical ventilation, admission to the intensive care unit, and mortality, independent of age, diabetes, and hypertension $[3,4]$.

There is increasing use of bioelectrode interfaces with wearable bioelectronics to enable the continuous non-invasive transfer of physiological information [5-10]. In addition, the detection of biochemical molecules to indicate physiology and metabolism can be achieved using wearable electrochemical biosensors [11-13]. These electrochemical bio-sensors are generally established on enzyme-electrochemical reactions with high specificity [14]. The key step for wearable electrochemical biosensors is the enzyme-electrode interface where 
the electron transfer takes (ET) place [15-17]. The ET between enzymes and electrodes is problematic, as the polypeptides are embedded with the enzymes at the redox-active center $[18,19]$. Accordingly, to overcome this issue, electron mediators have been used to enhance the enzyme-electrochemical reactions. However, cross-reaction and leakage of the electron mediators result in low selectivity and instability of the biosensors [20,21]. A wearable electrochemical biosensor with high sensitivity and selectivity for biochemical molecules requires direct ET at enzyme-electrode interfaces without electron mediators. For a wearable sensor, a sensing platform is also essential for reproducibility, real-time detection, and high sensitivity. In 2014, Google partnered with Novartis to develop a smart contact for real-time assessment of tear glucose levels but was subsequently abandoned as there was a poor correlation between blood glucose levels and tears.

Sensing glucose in sweat is easy and avoids penetrating the skin to access blood or interstitial fluid. The excretion of glucose in sweat primarily depends on blood glucose; for a healthy individual, the sweat glucose level is $0.02-0.6 \mathrm{mM}$ and $0.01-1 \mathrm{mM}$ for diabetic patients [22-26]. It has been suggested that the electrochemical analysis of glucose concentration in sweat could accurately reflect blood glucose levels $[27,28]$. Although a recent study showed no correlation between sweat and blood glucose concentrations after submaximal exercise, indicating that sweat composition is at least relatively independent of blood composition [29].

Enzymatic sensors relying on glucose oxidation have been developed to detect glucose from sweat with high sensitivity but have a short lifespan of 1-2 weeks [30]. Interfaces of biological components are not necessary for nonenzymatic glucose sensors, and, therefore, they are cheaper to fabricate and have a longer life span [31]. However, they are less efficient because of their high working potential, slow kinetics, and weak sensing parameters with poor selectivity and low sensitivity [32]. An alternative metal and metal oxide can be used at the interface of nanoporous gold to overcome some of these issues [33,34], but this is expensive and limits commercial usage since the fabrication of low-cost glucose sensors is a market prerequisite [35]. Prussian blue/hydrogen peroxide has been utilized to enhance glucose sensitivity and selectivity in sweat, but it lacks stability and selectivity. Nanomaterials have also shown excellent performance in sweat-based electrochemical glucose biosensing systems. However, nanomaterials such as $\mathrm{ZnO}$ nanowires, $\mathrm{Cu} \mathrm{NCs}$, CNTs cannot be used efficiently because of their high working potential, $\mathrm{pH}$ conditions, low kinetics, and sensing parameters [36]. Therefore, researchers have integrated nanomaterial having high electroconductive and large surface area with glucose oxidase (GOx) enzymes to enhance selectivity and sensitivity. It is worth mentioning that one research group synthesized hierarchical mesoporous CNTs to achieve a sensitivity of $270 \pm 10 \mu \mathrm{AmM}^{-1} \mathrm{~cm}^{-2}$. CuNi glucose-sensing includes good reproducibility, reusability, and stability given the controllable preparation of electrodes and the surface with a robust chemical state. The disadvantage is that glucose-sensing can only be achieved at higher $\mathrm{pH}$.

Glucose levels have primarily been evaluated from blood samples, although there is now increasing use of continuous glucose monitoring, relying on subcutaneous interstitial glucose levels [37-39]. This is particularly relevant to assess hypoglycemia, which can occur during Ramadan due to glucose-lowering therapies, particularly insulin [40,41]. Other body fluids such as sweat, saliva, and tears may also be utilized to assess glucose levels; however, the glucose amount in these body fluids is very low, and the sensing devices require high sensitivity to detect glucose. In this context, biosensors have high sensitivity and better stability than traditional methods of glucose detection [42]. Non-invasive glucose monitoring helps in continuous glucose monitoring by providing real-time and dynamic information about the glucose concentration. This method of glucose monitoring measures glucose without puncturing the skin to withdraw blood and without causing pain or trauma [43].

In this work, we have developed non-invasive glucose biosensing based on a $\mathrm{Ni}$ $\mathrm{Cu} /$ mesoporous carbon/GOx nanocomposite. The synthesis method is cost-effective and straightforward without bulky and expensive instruments. The prepared composite was 
analyzed using XRD and TEM, and cyclic voltammetry was performed at various glucose concentrations in sweat samples. In addition, chronoamperometry was used to evaluate the sensitivity and interference (fructose, sucrose, uric acid, and dopamine) performance of the electrode in artificial sweat samples for glucose detection at $\mathrm{pH} 12$.

\section{Experimental}

2.1. Materials

Sodium hydroxide was purchased from Scharlau, glucose and sucrose were purchased from Fisher scientific. Uric acid and fructose were bought from the Research lab; however, $\mathrm{NaCl}$ was purchased from Avonchem. Urea and lactic acid were bought from Alfa Aesar. Mesoporous carbon, copper acetate $\mathrm{Cu}\left(\mathrm{CH}_{3} \mathrm{COO}\right)_{2} \cdot 3 \mathrm{H}_{2} \mathrm{O}$ and nickel acetate $\mathrm{Ni}\left(\mathrm{CH}_{3} \mathrm{COO}\right)_{2} \cdot 6 \mathrm{H}_{2} \mathrm{O}, \mathrm{N}$, N-dimethylformamide (DMF) oleic acid, potassium chloride $\mathrm{KCl}$, dopamine, and oleylamine were purchased from Sigma Aldrich.

\subsection{Preparation of $C N M C$}

The bimetallic $\mathrm{Cu}$-Ni nanoparticles coated mesoporous carbon was obtained using the same method [11]. Briefly, $\mathrm{Cu}\left(\mathrm{CH}_{3} \mathrm{COO}\right)_{2} \cdot 3 \mathrm{H}_{2} \mathrm{O}$ and $\mathrm{Ni}\left(\mathrm{CH}_{3} \mathrm{COO}\right)_{2} \cdot 6 \mathrm{H}_{2} \mathrm{O}$ were placed in $20 \mathrm{~mL} \mathrm{~N}, \mathrm{~N}$-dimethylformamide (DMF). The mesoporous carbon was added to the solution and left for $24 \mathrm{~h}$ until a homogenous mixture was obtained. Oleic acid and oleylamine were added to the solution and heated to $180{ }^{\circ} \mathrm{C}$ for $8 \mathrm{~h}$ using a $75 \mathrm{~mL}$ sealed Teflon-lined stainless autoclave. The acquired product was centrifuged at 10,000 rpm for $30 \mathrm{~min}$ and washed several times using ethanol and deionized water. Subsequently, the dried powder is heated up to $700{ }^{\circ} \mathrm{C}$ for $2 \mathrm{~h}$ at a heating rate of $5{ }^{\circ} \mathrm{C}$ per minute under an argon gas flow to obtain the final product of the mixed $\mathrm{Cu}-\mathrm{Ni}$ nanoalloy decorated the mesoporous carbon (CuNi-MC).

\subsection{Fabrication of Electrode and Sweat Solution}

The catalyst ink was synthesized by adding $2 \mathrm{~mL}$ of ethanol to a mixture of $10 \mathrm{mg}$ $\mathrm{Ni} / \mathrm{Cu}$-mesoporous composite, $2 \mathrm{mg}$ GOx, and $40 \mu \mathrm{L}$ nafion. The mixture was kept for sonication in an ice bath for $1 \mathrm{~h}$. After that, $10 \mu \mathrm{L}$ of the suspension was dropped on the GC electrode's active surface, which was left to dry at room temperature for $1 \mathrm{~h}$ to obtain a uniform thin coating on the surface. The artificial sweat solution was synthesized using $5.5 \mathrm{mM}$ lactic acid, $22 \mathrm{mM}$ urea, $10 \mathrm{mM} \mathrm{KCl}$, and $25 \mathrm{mM}$ uric acid [13].

\subsection{Characterization Techniques}

The TEM analysis of the as-prepared catalyst was obtained by dispersing catalyst in IPA and a drop was left to dry on molybdenum grid to avoid interference with sample elements. A FEI-Thermo scientific-TALOS A FEG transmission electron microscope with a $200 \mathrm{kV}$ beam voltage was used. Elemental analysis and mapping was performed using a FEI-Thermo scientific-SuperX EDS detector. The XRD analysis was carried using Rigaku, Miniflex2 Desktop, Tokyo, Japan, equipped with $\mathrm{Cu} \mathrm{K}_{\alpha}$ radiations. The and phase study structural of the as-synthesized catalyst was carried out at a scanning step of $0.02^{\circ}$ in the $2 \theta$ range from $10^{\circ}$ to $90^{\circ}$. Gamry-potentiostat/galvanostat (Ref. 600) was employed to perform the cyclic voltammetry $(\mathrm{CV})$ and chronoamperometry experiments using a three-electrode cell configuration consisting of $\mathrm{Ag} / \mathrm{AgCl}$ electrode as a reference electrode, the GC as the working electrode, and platinum wire as a counter electrode. The cyclic voltammetry was conducted at a potential range from $-0.1 \mathrm{~V}$ to $0.8 \mathrm{~V}$ vs. $\mathrm{Ag} / \mathrm{AgCl}$ at $25 \mathrm{mV} / \mathrm{s}$, and the chronoamperometry was done at an applied potential of $0.6 \mathrm{~V}$.

\section{Results and Discussion}

\subsection{XRD and TEM}

Figure 1a shows the TEM image of the used mesoporous carbon synthesizing the CuNi-MC catalyst with less than $100 \mathrm{~nm}$ particle size. The XRD pattern of CuNi-MC is 
presented in Figure 1b. The average crystal size was estimated from the XRD patterns using the Debye-Scherer equation.

$$
\mathrm{D}=\frac{0.9 \lambda}{\beta \cos \theta}
$$

where $D$ is the crystallite size, $\lambda$ is the wavelength of $C u-k_{\alpha 1}=1.54060 \AA, \beta$ can be estimated from the experimental peak width (FWHM) of the most intense peak (002). The average crystal size of the bimetallic $\mathrm{Ni}-\mathrm{Cu}$-nanoparticles was calculated in the range of $10 \pm 2 \mathrm{~nm}$. The amorphous peak positioned at $24.8^{\circ}$ was attributed to the mesoporous carbon. However, the peaks located at $43.9^{\circ}, 51.1^{\circ}$, and $75.1^{\circ}$ are related to $d$ values of $2.06,1.78$, and $1.26 \AA$, which are accredited to the well-determined (111), (200), and (220) crystallographic planes of the bimetallic $\mathrm{Cu}-\mathrm{Ni}$ nanoparticles, respectively $[23,44]$.
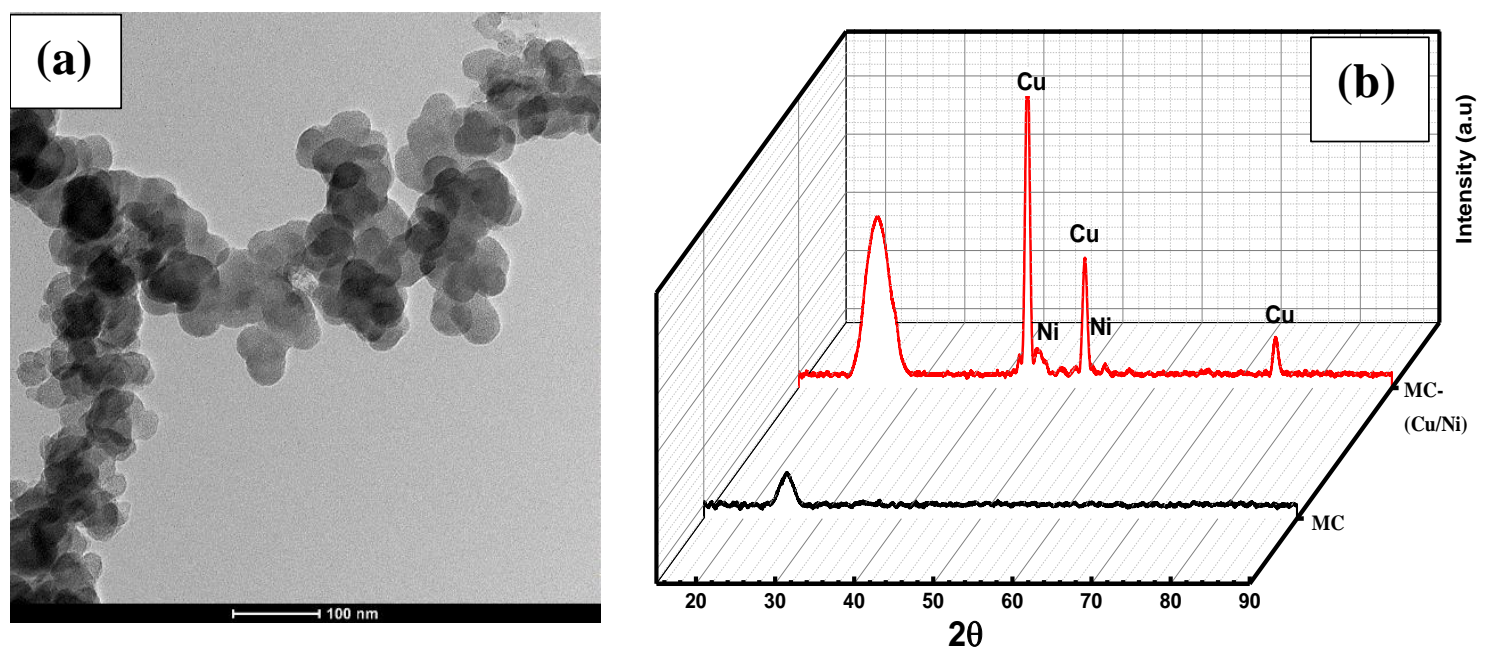

Figure 1. (a) TEM image of the used mesoporous carbon for catalyst synthesis and (b) XRD of bimetallic CuNi nanoparticlecoated mesoporous carbon.

The morphological studies of the as-prepared catalyst were explored using TEM (Figure 2a). The bimetallic $\mathrm{Cu} / \mathrm{Ni}$ nanoparticles have a spherical shape attached to the mesoporous carbon surface with an average size of $22 \pm 5 \mathrm{~nm}$. The STEM and elemental mapping analysis illustrated the construction of mixed $\mathrm{Cu} / \mathrm{Ni}$ nanoalloy, see Figure $2 \mathrm{~b}-\mathrm{f}$.

\subsection{Electrochemical Studies}

The glucose sensitivity of the as-prepared catalyst was evaluated at variable $\mathrm{pH}$ of 7 and 12. Figure 3a shows the $\mathrm{CV}$ of the glucose sensor at $\mathrm{pH} 7$, exhibiting no oxidationreduction peaks. Similar studies have been carried out exploring the effect of the $\mathrm{pH}$ on the electrode sensitivity, revealing that the catalyst sensitivity to glucose is boosted by increasing the $\mathrm{pH}$ [45-47]. The reduced species transferred the excess electrons to the $\mathrm{Ni}^{2+} / \mathrm{Ni}^{3+}$ redox couple leading to an enhancement in the redox current. It is worth mentioning that ion contamination limitation can be eliminated employing alkaline conditions on the electrode surface, as the hydroxyl groups $\left(\mathrm{OH}^{-}\right)$suppress the chloride $\left(\mathrm{Cl}^{-}\right)$adsorption to the electrode surface $[45,47]$. Accordingly, changing the real $\mathrm{pH}$ of the sweat solution in this work significantly enhanced the sensitivity of the as-prepared electrode. Figure $3 b, c$ exhibited the $\mathrm{CV}$ of the as-synthesized catalyst in the absence and presence of glucose oxidase, showing a distinct variation in their response to glucose. This was ascribed to the glucose oxidation by GOx enzyme-generating $\mathrm{H}_{2} \mathrm{O}_{2}$, which was reduced to $\mathrm{H}_{2} \mathrm{O}+\mathrm{O}_{2}$ at $\mathrm{CuNi}-\mathrm{MC}$ surface and consequently increased the electrocatalytic currents. 


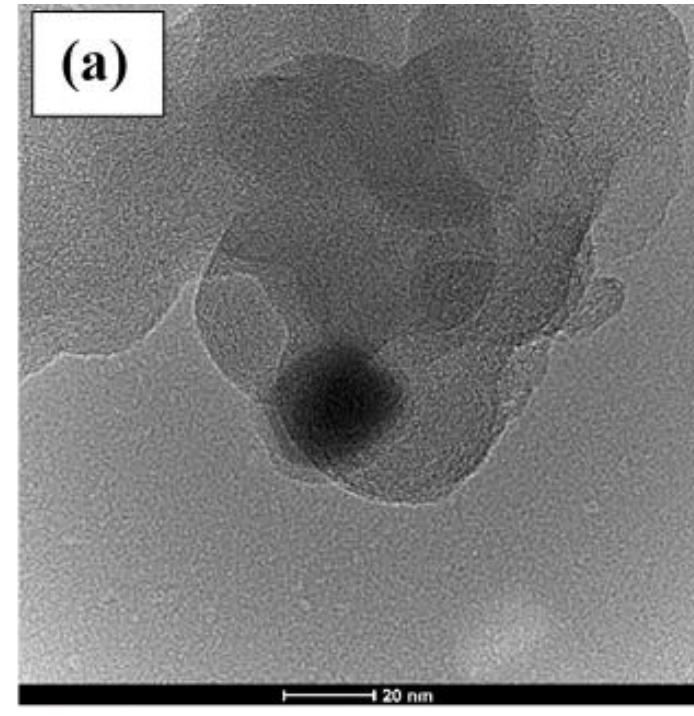

(b)
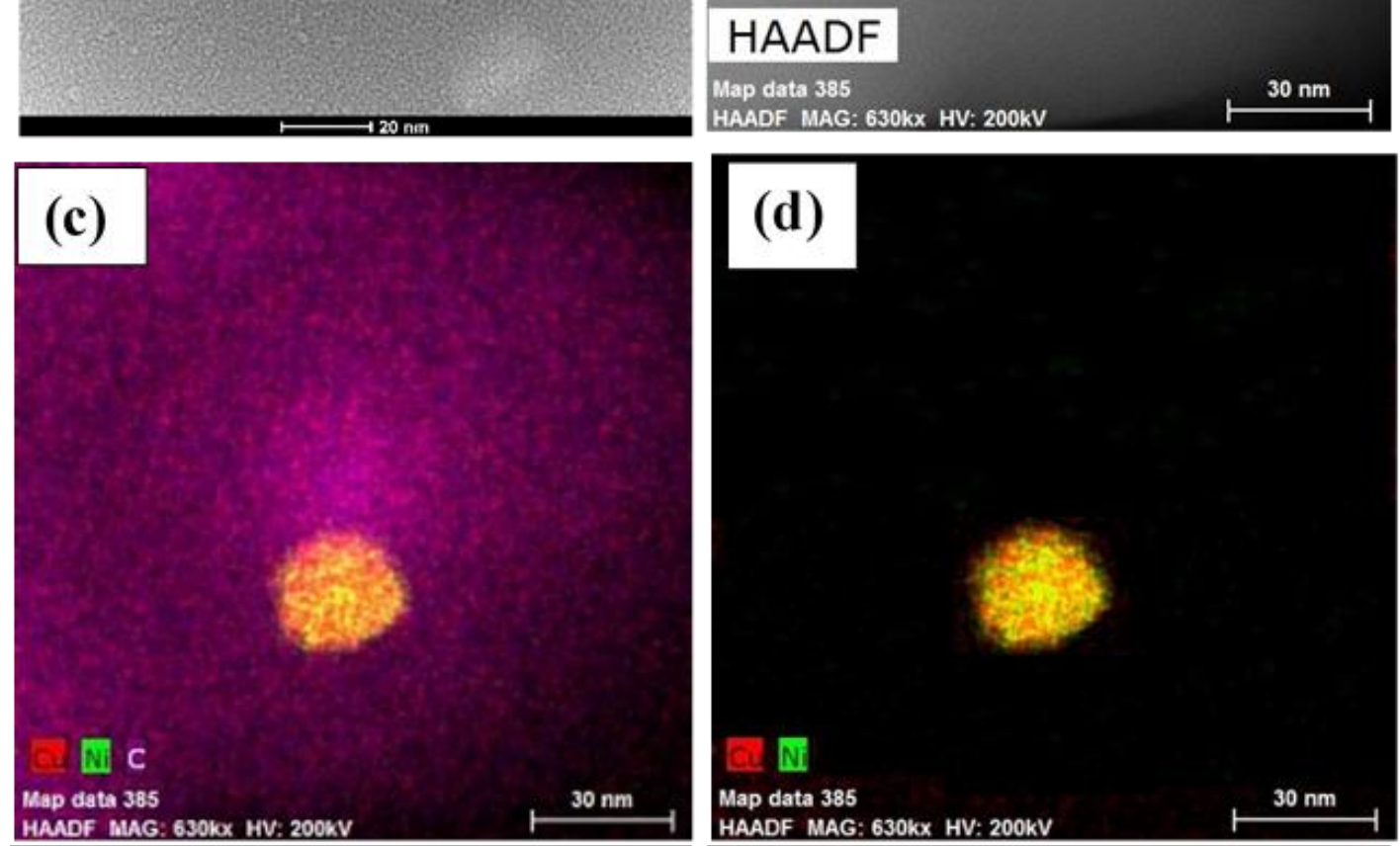

\section{(e)}

(f)
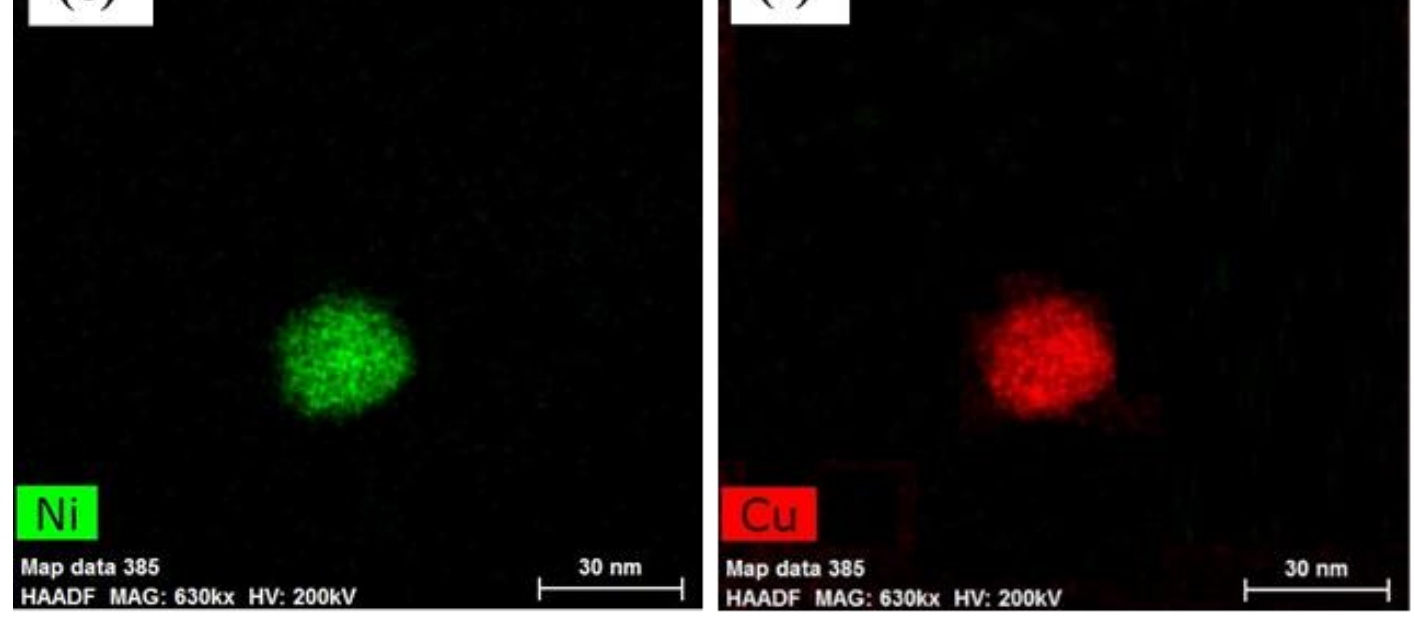

Figure 2. (a) TEM BF image of the CuNi-MC and (b) High-angle annular dark-field (HAADF)-STEM image, (c-f) shows elemental mapping images of bimetallic CuNi nanoparticle-coated mesoporous carbon. 

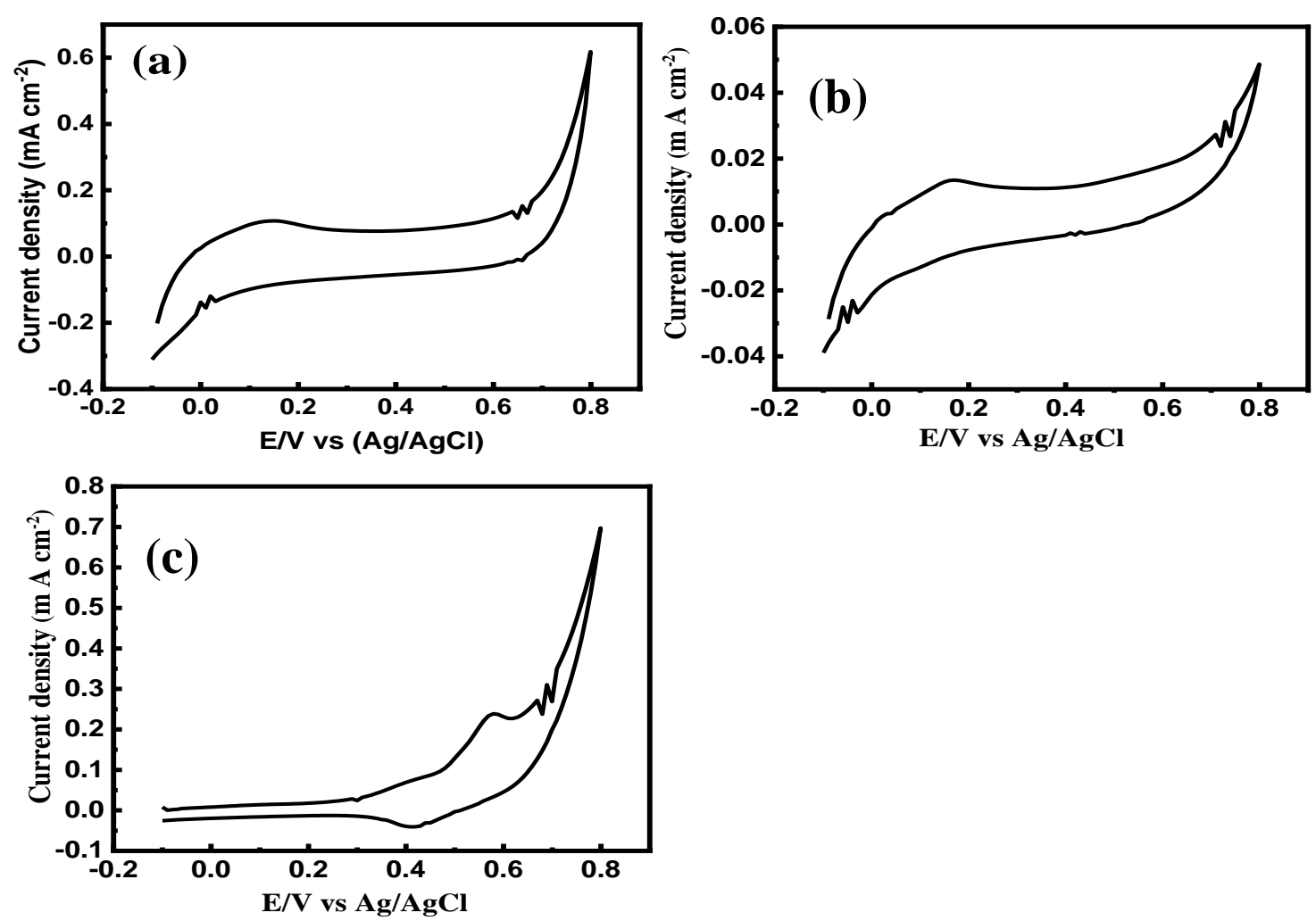

Figure 3. (a) CV of the enzymatic CuNi-MC in sweat solution after adding glucose of $0.11 \mathrm{mM}$ at $\mathrm{pH}$ 7. The CV of CuNi-MC in sweat solution $(\mathbf{b})$ before $(\mathbf{c})$ after the addition of the glucose oxidase $(0.11 \mathrm{mM})$ at $\mathrm{pH} 12$. For all measurements, a scan rate was $50 \mathrm{mV} \mathrm{s}^{-1}$.

Figure 4 shows the $\mathrm{CV}$ of the electrode modified with $\mathrm{CuNi}-\mathrm{MC}$ in sweat solution at different concentrations of glucose. The redox peak potential of $\mathrm{CuNi}$-MC could be linked to the redox couple of $\mathrm{Ni}^{2+}$ to $\mathrm{Ni}^{3+}$ and $\mathrm{Cu}^{2+}$ to $\mathrm{Cu}^{3+}$ and then back to $\mathrm{Ni}^{2+}$ and $\mathrm{Cu}^{2+}$. This finding indicates that the direct electrochemical reaction of $\mathrm{GO}_{\mathrm{x}}$ occurs on the $\mathrm{CuNi}$ $\mathrm{MC} / \mathrm{GO}_{\mathrm{x}}$ electrode surface, with $\mathrm{GO}_{\mathrm{x}}$ maintaining its electroactivity on the $\mathrm{CuNi}-\mathrm{MC} / \mathrm{GO}_{\mathrm{x}}$ surface. The current density increased by adding a higher amount of glucose, which could be accredited to the existence of many active sites due to the porous structure of the mesoporous carbon resulting in a high electron transfer rate. $\mathrm{A} \mathrm{Ni}(\mathrm{OH})_{2}$ (Equation (5)) film is first constructed on the bimetallic $\mathrm{CuNi}$ surface, leading to $\mathrm{Cu}$ enrichment on the metal surface followed by oxidation to $\mathrm{CuO}$ and $\mathrm{Cu}(\mathrm{OH})_{2}$ (Equations (2) and (3)). Consequently, the film surface is composed of $\mathrm{Cu}(\mathrm{OH})_{2}$ and $\mathrm{NiOOH}$, providing high electrical conductivity for the reaction [48]. Moreover, some $\mathrm{CuO}$ and $\mathrm{Cu}(\mathrm{OH})_{2}$ can be further oxidized to $\mathrm{Cu}^{3+}$ oxide [49]. Mathew et al. [50] demonstrated that an electroactive species of $\mathrm{Ni}(\mathrm{OH})_{2}$ could be reconstructed with a predominant $\alpha$-structure during the reaction of $\gamma-\mathrm{NiO}(\mathrm{OH})$ with glucose while testing their enzymatic nickel hydroxide sensor in an alkaline medium. The generated $\alpha-\mathrm{Ni}(\mathrm{OH})_{2}$ will be oxidized to $\gamma-\mathrm{NiO}(\mathrm{OH})$ during the redox reaction, boosting the anodic current. Consequently, concentrated $\mathrm{Ni}^{3+}$ will be formed on the surface and reduced to $\mathrm{Ni}^{2+}$ during the glucose oxidation reaction, increasing the cathodic current. It is worth mentioning that few of $\gamma-\mathrm{NiO}(\mathrm{OH})$ species could be converted to $\beta-\mathrm{Ni}(\mathrm{OH})_{2}$, generating $\mathrm{NiH}$ or $\mathrm{NiO}$ as an irreversible reaction since the test was carried out in an alkaline medium where $\alpha-\mathrm{Ni}(\mathrm{OH})_{2}$ was not stable [50]. Nonetheless, the presence of higher content of $\mathrm{Ni}^{2+}$ and $\mathrm{Ni}^{3+}$ ions on the surface, smaller conversions could slightly influence the redox reaction and current [50]. Nevertheless, the bimetallic $\mathrm{CuNi}$ nanoparticles can efficiently restrain the unfavorable $\gamma-\mathrm{NiOOH}$ species construction, stabilizing $\beta-\mathrm{NiOOH}$ forms at $\mathrm{pH} 12$ [51]. The presence of $\beta-\mathrm{NiOOH}$ species is considered to be an improved electroactive phase for superior electrochemical performance in an 
alkaline medium [52]. The presence of the $\mathrm{CuNi}$ bimetallic nanospecies facilitates the $\mathrm{e}^{-}$ transfer between the GC surface and the $\mathrm{GO}_{\mathrm{x}}$, improving glucose detection.

$$
\begin{gathered}
\mathrm{Cu}+2 \mathrm{OH}^{-} \rightarrow \mathrm{CuO}+\mathrm{H}_{2} \mathrm{O}+2 \mathrm{e}^{-} \\
\mathrm{CuO}+\mathrm{H}_{2} \mathrm{O} \rightarrow \mathrm{Cu}(\mathrm{OH})_{2} \\
\mathrm{Cu}(\mathrm{OH})_{2}+2 \mathrm{OH}^{-} \rightarrow \mathrm{CuOOH}+\mathrm{H}_{2} \mathrm{O}+2 \mathrm{e}^{-} \\
\mathrm{Ni}+2 \mathrm{OH}^{-} \rightarrow \mathrm{Ni}(\mathrm{OH})_{2}+2 \mathrm{e}^{-} \\
\mathrm{Ni}(\mathrm{OH})_{2}+2 \mathrm{OH}^{-} \rightarrow \mathrm{NiOOH}+\mathrm{H}_{2} \mathrm{O}+2 \mathrm{e}^{-}
\end{gathered}
$$

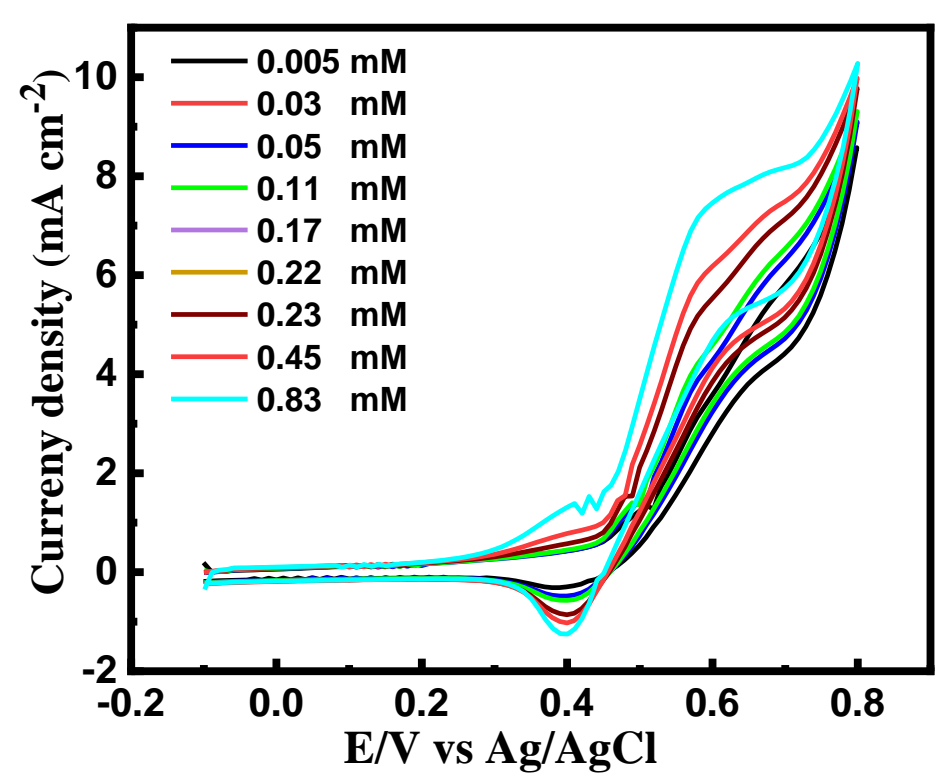

Figure 4. The cyclic voltammetric response of $\mathrm{Cu}-\mathrm{Ni}$ modified electrode on sweat solution at $\mathrm{pH} 12$ and a scan rate of $50 \mathrm{mV} \mathrm{s}^{-1}$.

Scheme 1 describes the glucose-sensing mechanism of the enzymatic biosensor. GOx catalyzes the glucose oxidation to gluconolactone in the existence of oxygen while generating $\left(\mathrm{H}_{2} \mathrm{O}_{2}\right)$ hydrogen peroxide and water as by-products. In addition, further carboxylic acid, gluconic acid are formed as a result of the reaction of gluconolactone and water. On the other hand, $\left(\mathrm{FAD}^{+}\right)$flavin adenine dinucleotide is employed as a redox cofactor for GOx to perform this oxidation reaction. $\mathrm{FAD}^{+}$acts as an electron acceptor, which will be reduced to $\mathrm{FADH}_{2}$ during the redox process [53]. Subsequent reaction with $\left(\mathrm{O}_{2}\right)$ to yield hydrogen peroxide revive the $\mathrm{FAD}^{+}$cofactor. This process takes place at the anode surface, where the number of transferred electrons can be interrelated to the quantity of generated $\mathrm{H}_{2} \mathrm{O}_{2}$ and, therefore, the glucose content [53].

$$
\begin{aligned}
\mathrm{GO}_{\mathrm{x}}(\mathrm{FAD})+\text { Glucose } & \rightarrow \mathrm{GO}_{\mathrm{x}}\left(\mathrm{FADH}_{2}\right)+\text { Gluconolactone } \\
\mathrm{GO}_{\mathrm{x}}\left(\mathrm{FADH}_{2}\right) & \rightarrow \mathrm{GO}_{\mathrm{x}}(\mathrm{FAD})+2 \mathrm{e}^{-}+2 \mathrm{H}^{+} \\
\mathrm{NiOOH}+\text { Glucose } & \rightarrow \mathrm{Ni}(\mathrm{OH})_{2}+\text { Gluconolactone } \\
\mathrm{CuOOH}+\text { Glucose } & \rightarrow \mathrm{Cu}(\mathrm{OH})+\text { Gluconolactone }
\end{aligned}
$$




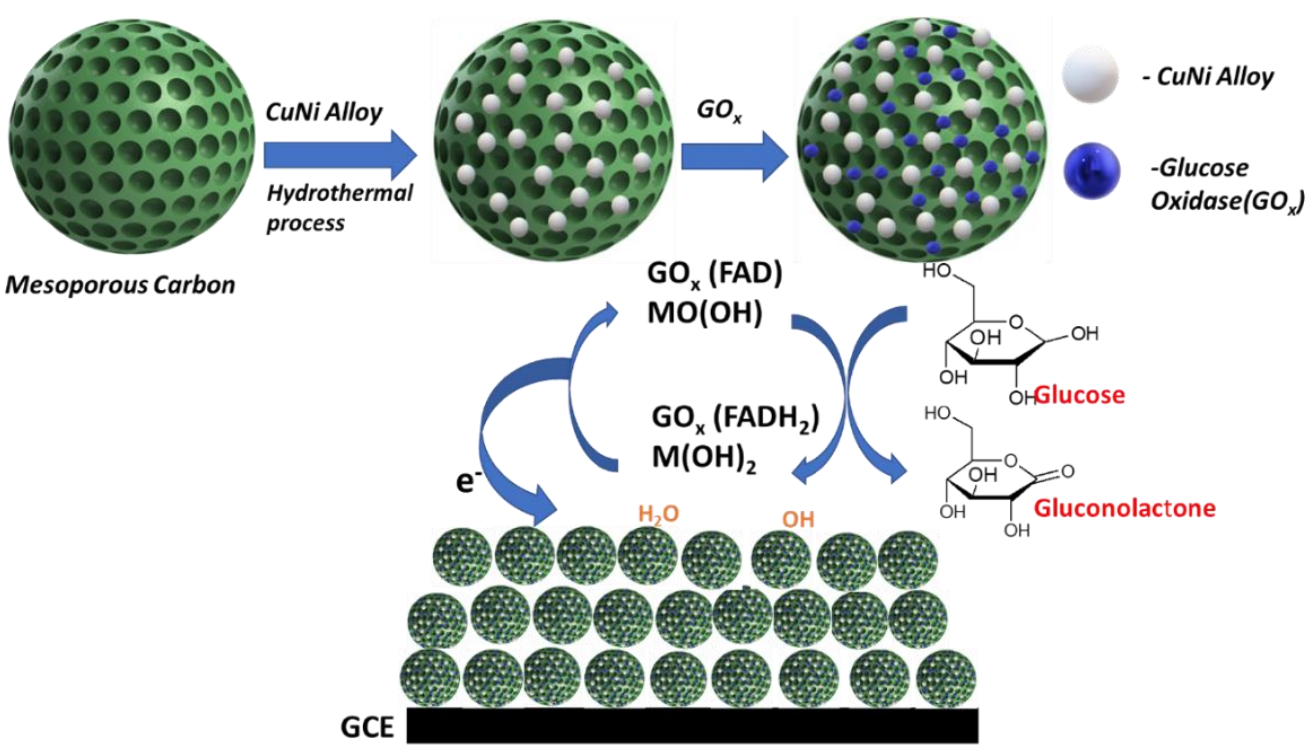

Scheme 1. Schematic illustration for glucose sensing mechanism based on CuNi-MC/GO catalyst.

The electrochemical behavior of $\mathrm{CuNi}-\mathrm{MC}$ was explored at a scan rate that varied from 5 to $150 \mathrm{mV} / \mathrm{s}$ in sweat solution (Figure 5a). It is noteworthy that by increasing the scan rate, the hydroxide ions $\left(\mathrm{OH}^{-}\right)$penetrate the generated $\mathrm{Ni}(\mathrm{OH})_{2}$ layer giving rise to thickening the $\mathrm{NiOOH}$ wrought layer [54]. Both cathodic and anodic peak currents increased in proportion to the scan rates with a linear regression formula of $\mathrm{i}_{\mathrm{pa}}=0.186-0.02 \mathrm{v}^{1 / 2}$ $(\mathrm{n}=10, \mathrm{R}=0.9967)$ and $\mathrm{i}_{\mathrm{pc}}=-0.034+0.019 \mathrm{v}^{1 / 2}(\mathrm{n}=10, \mathrm{R}=0.9943)$, see Figure $5 \mathrm{~b}$. These outcomes specify that the electrochemical process of $\mathrm{Ni}(\mathrm{OH})_{2} / \mathrm{NiOOH}$ transformation is diffusion-controlled [54,55]. The $\mathrm{i}_{\mathrm{pc}}$ shifted to higher negative values, and the $\mathrm{i}_{\mathrm{pa}}$ shifted positively by increasing the scan rates, leading to a larger peak-to-peak potential separation. The response of CuNi nanoalloys to glucose electro-oxidation is considerably better than that of pure $\mathrm{Cu}$ or $\mathrm{Ni}$ due to the synergistic electrochemical influence of the bimetallic nanoparticles since the unalloyed $\mathrm{Ni}$ is not robust under highly oxidizing conditions, and $\mathrm{Cu}$ has a stabilizing influence on the Ni surface [56].
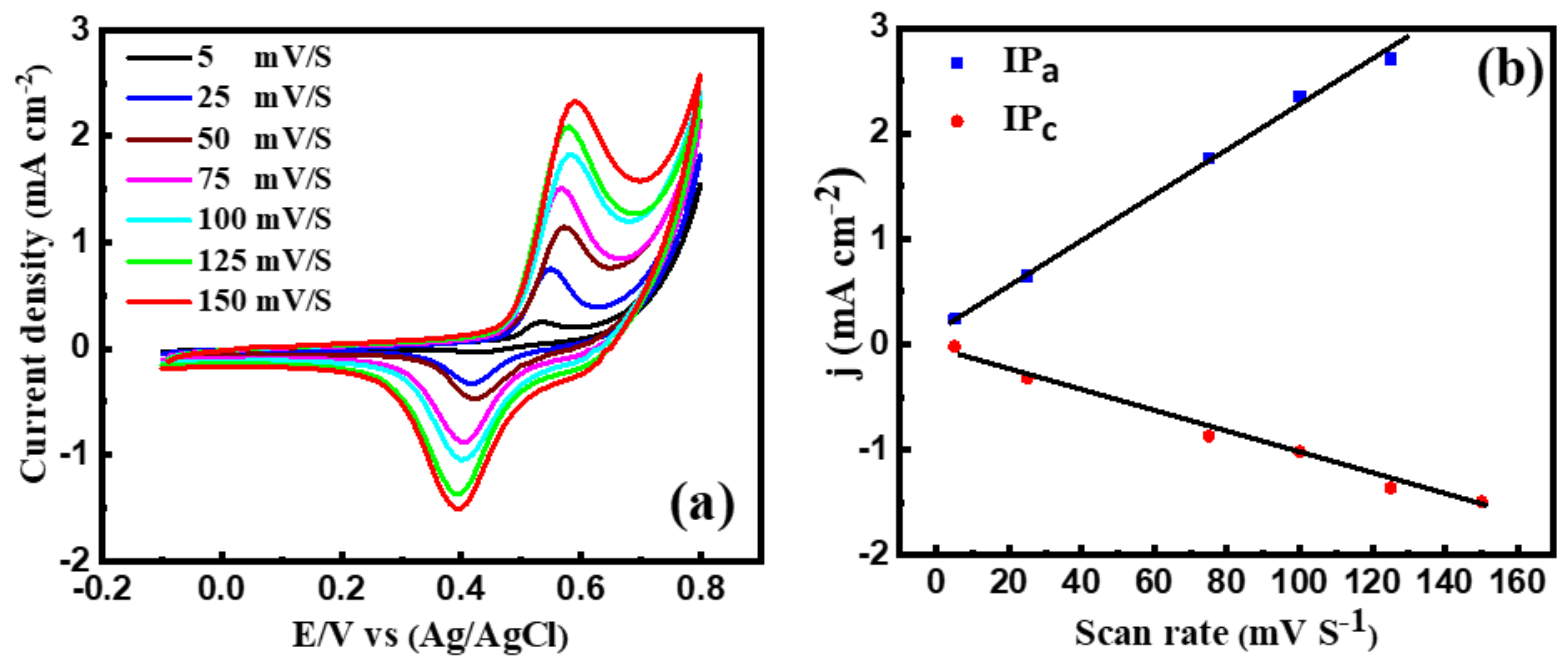

Figure 5. (a) Cyclic voltammograms (CVs) of CuNi-MC at different scan rates and (b) peak current density as a function of scan rates at $\mathrm{pH} 12$. 


\subsection{Chronoamperometric Studies}

Figure 6a shows the corresponding amperometric response for the CuNi-MC/GOx based glucose sensor. With increasing the glucose content from $5 \mu \mathrm{m}$ to $0.45 \mathrm{mM}$, the response of the modified electrode was enhanced due to the enhanced conductivity of the catalyst. Figure $6 \mathrm{~b}$ exhibits a calibration plot between glucose and the current response of CuNi-MC/GOx modified electrode. The sensor showed a sensitivity of $11.7 \pm 0.061 \mathrm{~mA} \mathrm{mM} \mathrm{cm}^{-2}$ with a linear range of 0.005 to $0.45 \mathrm{mM}$ and a response time of $4 \mathrm{~s}$. This can be explained by the high electrocatalytic activity of the as-prepared catalyst, which acquires the uniformity of the glucose oxidase (GOx) enzyme to perform the electrochemical reaction between the electrode and glucose analyte. Some easily oxidizable compounds such as fructose, sucrose, dopamine, and uric acid coexist with glucose in human sweat. The selectivity of these compounds was analyzed with amperometric measurements concerning glucose concentration. There is no substantial interference with uric acid, dopamine, fructose, and sucrose (Figure 6c). The molecular size of mesoporous carbon is $50 \mathrm{~nm}$, whereas the molecular size of glucose is $0.9 \mathrm{~nm}$. This might be the reason for enhancement in glucose sensitivity, as the glucose can be entrapped in the sites of the mesoporous carbon and interact with GOx enzyme with an increased surface area. Additionally, the molecular size of the other interacting species such as uric acid, dopamine, fructose, and sucrose is more or less similar to glucose. Nevertheless, the presence of GOx enzyme enhances the selectivity of glucose by interacting with the glucose molecules. Therefore, the mesoporous carbon coated on $\mathrm{Cu}-\mathrm{Ni}$ is selective towards glucose rather than interfering species.
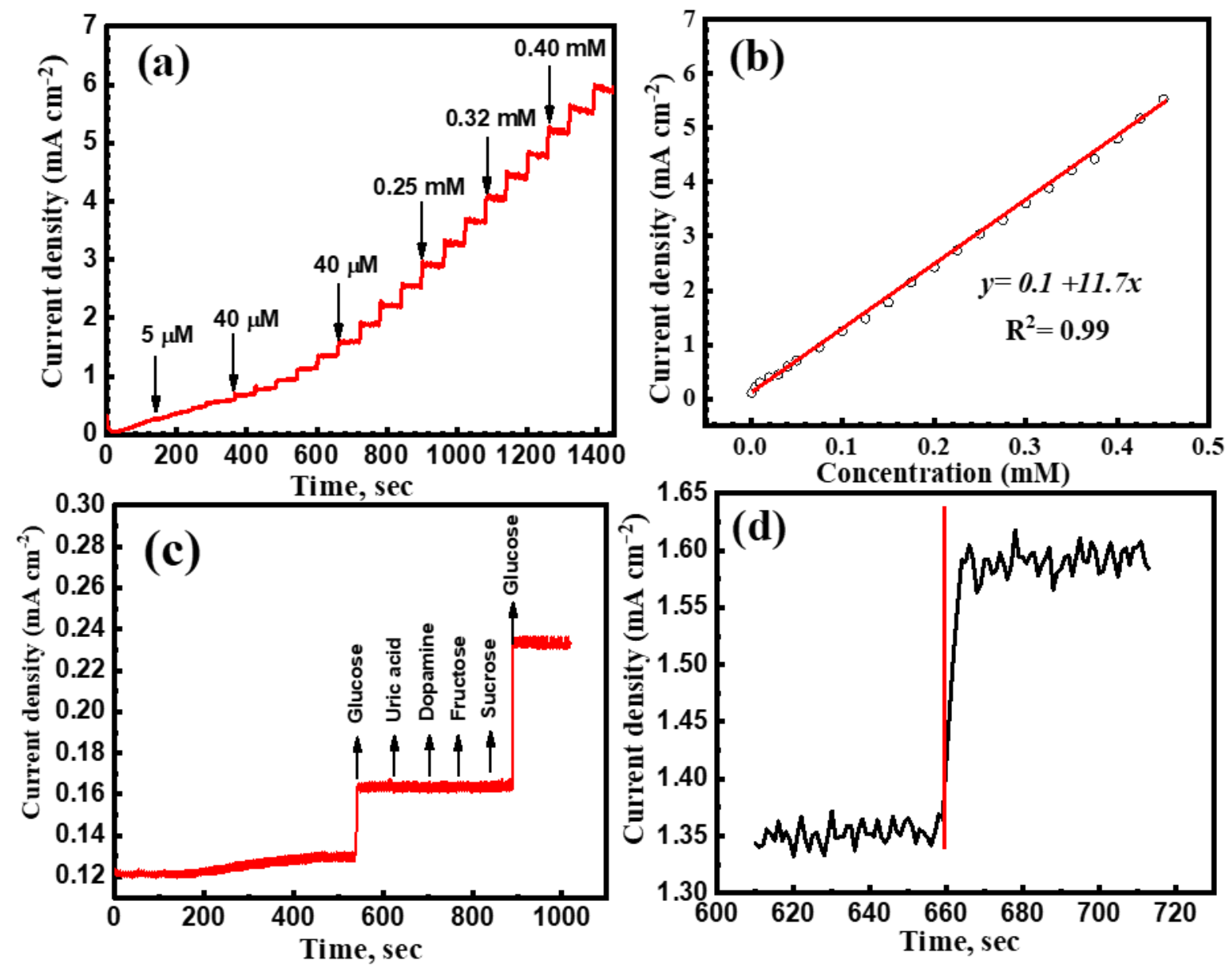

Figure 6. The chronoamperometric response of the mesoporous carbon coated with CuNi-MC sensor to (a) successive additions of higher glucose concentration, (b) calibration curve including the linear range, (c) after the addition of $40 \mu \mathrm{M}$ glucose, uric acid, dopamine, fructose, and sucrose at $\mathrm{pH} 12$ and $-0.6 \mathrm{~V}(\mathrm{Ag} / \mathrm{AgCl})$ and (d) response time of the sensor to reach steady-state current density after the addition of $40 \mu \mathrm{M}$ glucose. 
The limit of detection ( $\mathrm{LOD}=5.2 \mu \mathrm{m} \mathrm{L}^{-1}$ ) is calculated employing the following formula.

$$
\mathrm{LOD}=\frac{3 \sigma}{\mathrm{m}}
$$

where $\sigma$ and $\mathrm{m}$ correspond to the standard deviation of the linear range produced after the addition of glucose and the slope of the fitted calibration curve, respectively.

Figure $6 \mathrm{~d}$ displayed that a fast current response was attained upon adding $40 \mu \mathrm{M}$ glucose, reaching the steady-state current in less than $4 \mathrm{~s}$. The rapid response time exhibits competent activity of the as-prepared catalyst toward glucose sensing.

The stability of the as-prepared catalyst has been assessed by recording the current response of the redox couple in $1 \mathrm{mM}$ glucose solution after 20 consecutive voltammetric cycles, see Figure 7. It is worth mentioning that the redox current response has insignificantly reduced after a continuous scan of 20 cycles, demonstrating that the as-prepared sensor is robust and stable.

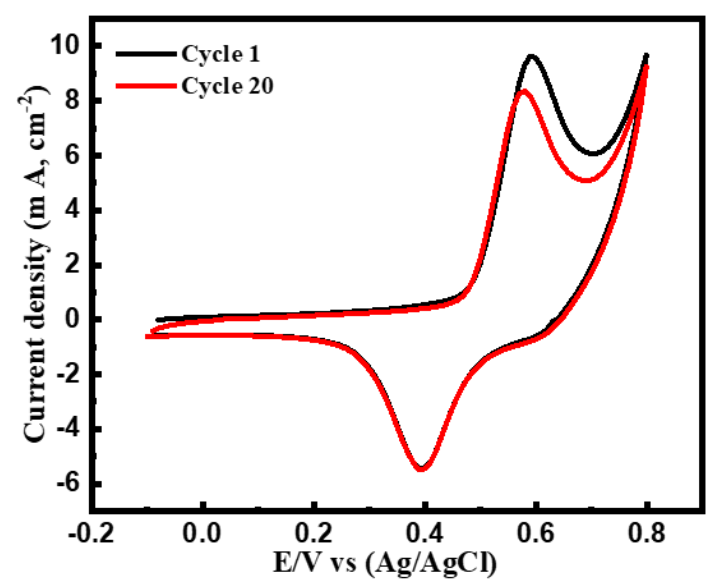

Figure 7. Cyclic voltammetric response of $\mathrm{CuNi}-\mathrm{MC}$ electrode in $1 \mathrm{mM}$ glucose solution at the first cycle and after 20 cycles at a scan rate of $50 \mathrm{mV} \mathrm{s}^{-1}$.

Table 1 shows a comparative study of the mesoporous carbon's sensitivity with Ni-Cu on glucose with different modified electrodes. The electrocatalytic activity with glucose for the electrode is depicted in terms of the electrode's high sensitivity. We introduced the mesoporous carbon along with $\mathrm{CuNi}$, which enhanced the glucose sensitivity as the surface area for glucose interaction increased. The highly conductive mesoporous carbon increases the electron transport, which results in high sensitivity of glucose. The electrode modified with mesoporous carbon coated with $\mathrm{Ni}-\mathrm{Cu}$ shows high sensitivity compared to other electrodes considered here.

Table 1. Comparative study of the as-prepared electrode with enzymatic electrochemical glucose sensors.

\begin{tabular}{|c|c|c|c|c|}
\hline Sensor & $\begin{array}{c}\text { Sensitivity } \\
\left(\mu \mathrm{A} \mathrm{mM} \mathrm{cm} \mathrm{cm}^{-2}\right)\end{array}$ & Linear Range & $\begin{array}{c}\text { LOD } \\
(\mu \mathrm{m} / \mathrm{L})\end{array}$ & Ref. \\
\hline $\mathrm{CuNi} / \mathrm{MC} / \mathrm{GO}_{\mathrm{x}} /$ Nafion/GCE & $11.7 \times 10^{3}$ & $5-450 \mu \mathrm{M}$ & 5.2 & Current work \\
\hline $\mathrm{Au}-\mathrm{NiO} / \mathrm{Ni}(\mathrm{OH})_{2}-\mathrm{GOx}$ & 1.95 & up to $30 \mathrm{mM}$ & $1.54 \times 10^{3}$ & [57] \\
\hline $\begin{array}{c}\text { GOx/Cu-hemin } \\
\text { MOFs }\end{array}$ & 22.77 & $9.1 \mu \mathrm{M}-36 \mathrm{mM}$ & 2.73 & [58] \\
\hline $\begin{array}{c}\mathrm{GOx} / \mathrm{Au}-\mathrm{ZnO} / \\
\mathrm{GCE}\end{array}$ & 1.409 & $1-20 \mathrm{mM}$ & 20 & [59] \\
\hline $\begin{array}{c}\text { PtNWA/AuNP/ } \\
\text { GOx }\end{array}$ & 184 & $15 \mu \mathrm{M}-2.5 \mathrm{mM}$ & 15 & {$[60]$} \\
\hline GOx/CoS-MWCNTs/Nafion/GCE & $14.9 \times 10^{3}$ & $0.008-1.5 \mathrm{mM}$ & 5 & [61] \\
\hline
\end{tabular}




\section{Conclusions}

The composite mesoporous carbon coated with $\mathrm{Ni}-\mathrm{Cu}$ nanoparticles can be used to fabricate wearable sensors to detect the amount of glucose in sweat. The as-synthesized catalyst's structural and morphological properties were assessed using XRD and TEM techniques. The electrochemical analysis showed a high electroactivity of the as-synthesized catalyst to glucose electro-oxidation. The catalyst exhibited glucose sensitivity at a wide linear range from 0.005 to $0.45 \mathrm{mM}$, a low detection limit of $5.2 \mu \mathrm{M}(\mathrm{S} / \mathrm{N}=3)$, high sensitivity of $11.7 \mathrm{~mA} \mathrm{mM} \mathrm{cm}{ }^{-2}$, and a fast response time of $4 \mathrm{~s}$. The fabricated electrode's sensitivity range was compared with other previously established electrodes suggesting that the composite is a promising material for the fabrication of wearable sensors for glucose detection. The high sensitivity and selectivity of the glucose sensor can be explained on the basis of the molecular structure and its integrations.

Author Contributions: Conceptualization, A.B.R.; methodology, A.B.R.; validation, A.B.R., S.P. and K.K.S.; formal analysis, A.B.R. and S.P.; resources, J.-J.C., R.A.M., P.K., R.A.S. and K.K.S.; data curation, J.-J.C., A.K.A.-A., R.A.M. and K.K.S.; writing-original draft preparation, A.B.R. and S.P.; writing-review and editing, J.-J.C., A.K.A.-A., P.K., R.A.S., R.A.M., S.A.M. and K.K.S.; supervision, A.B.R. and K.K.S.; funding acquisition, R.A.M. All authors have read and agreed to the published version of the manuscript.

Funding: This research was funded by Qatar National Research Fund grant number NPRP11S0110-180247.

Institutional Review Board Statement: Not applicable.

Informed Consent Statement: Not applicable.

Acknowledgments: This work was supported by an NPRP grant from the Qatar National Research Fund under the grant number NPRP11S-0110-180247. The statements made herein are solely the responsibility of the authors. The authors would like to acknowledge the support of Jana Ponraj and QEERI Core Labs., Hamad Bin Khalifa University, Qatar Foundation, Qatar, for TEM support.

Conflicts of Interest: The authors declare no conflict of interest.

\section{References}

1. Lin, X.; Xu, Y.; Pan, X.; Xu, J.; Ding, Y.; Sun, X.; Song, X.; Ren, Y.; Shan, P.-F. Global, Regional, and National Burden and Trend of Diabetes in 195 Countries and Territories: An Analysis from 1990 to 2025. Sci. Rep. 2020, 10, 14790. [CrossRef]

2. Saeedi, P.; Petersohn, I.; Salpea, P.; Malanda, B.; Karuranga, S.; Unwin, N.; Colagiuri, S.; Guariguata, L.; Motala, A.A.; Ogurtsova, K.; et al. Global and Regional Diabetes Prevalence Estimates for 2019 and Projections for 2030 and 2045: Results from the International Diabetes Federation Diabetes Atlas, 9th Edition. Diabetes Res. Clin. Pract. 2019, 157, 107843. [CrossRef] [PubMed]

3. Chen, M.; Zhou, H.; Liu, X.; Yuan, T.; Wang, W.; Zhao, C.; Zhao, Y.; Zhou, F.; Wang, X.; Xue, Z.; et al. Single Iron Site Nanozyme for Ultrasensitive Glucose Detection. Small 2020, 16, 2002343. [CrossRef] [PubMed]

4. Carrasco-Sánchez, F.J.; López-Carmona, M.D.; Martínez-Marcos, F.J.; Pérez-Belmonte, L.M.; Hidalgo-Jiménez, A.; Buonaiuto, V.; Fernández, C.S.; Castro, S.J.F.; Luordo, D.; Fontan, P.M.P.; et al. Admission Hyperglycaemia as a Predictor of Mortality in Patients Hospitalized with COVID-19 Regardless of Diabetes Status: Data from the Spanish SEMI-COVID-19 Registry. Ann. Med. 2021, 53, 103-116. [CrossRef]

5. Rogers, J.; Bao, Z.; Lee, T.-W. Wearable Bioelectronics: Opportunities for Chemistry. Accounts Chem. Res. 2019, 52, 521-522. [CrossRef] [PubMed]

6. Imani, S.; Bandodkar, A.J.; Mohan, A.M.V.; Kumar, R.; Yu, S.; Wang, J.; Mercier, P.P. A Wearable Chemical-Electrophysiological Hybrid Biosensing System for Real-Time Health and Fitness Monitoring. Nat. Commun. 2016, 7, 11650. [CrossRef]

7. Bandodkar, A.J.; Wang, J. Non-Invasive Wearable Electrochemical Sensors: A Review. Trends Biotechnol. 2014, 32, 363-371. [CrossRef]

8. Zhang, X. Nanowires Pin Neurons: A Nano "Moon Landing". Matter 2019, 1, 560-562. [CrossRef]

9. Dong, Q.; Ryu, H.; Lei, Y. Metal Oxide Based Non-Enzymatic Electrochemical Sensors for Glucose Detection. Electrochim. Acta 2021, 370, 137744. [CrossRef]

10. Bai, J.; Beyer, S.; Trau, D. Conjugated Polymers for Biosensor Devices. In Comprehensive Biomaterials; Ducheyne, P., Ed.; Elsevier: Oxford, UK, 2011; pp. 529-556. [CrossRef]

11. Pankratov, D.; González-Arribas, E.; Blum, Z.; Shleev, S. Tear Based Bioelectronics. Electroanalysis 2016, 28, 1250-1266. [CrossRef]

12. Kim, J.; Imani, S.; de Araujo, W.R.; Warchall, J.; Valdés-Ramírez, G.; Paixao, T.R.L.C.; Mercier, P.P.; Wang, J. Wearable Salivary Uric Acid Mouthguard Biosensor with Integrated Wireless Electronics. Biosens. Bioelectron. 2015, 74, 1061-1068. [CrossRef] [PubMed] 
13. Gao, W.; Emaminejad, S.; Nyein, H.Y.Y.; Challa, S.; Chen, K.; Peck, A.; Fahad, H.M.; Ota, H.; Shiraki, H.; Kiriya, D.; et al. Fully Integrated Wearable Sensor Arrays for Multiplexed In Situ Perspiration Analysis. Nature 2016, 529, 509-514. [CrossRef]

14. Bollella, P.; Gorton, L. Enzyme based Amperometric Biosensors. Curr. Opin. Electrochem. 2018, 10, 157-173. [CrossRef]

15. Kim, J.; Jeerapan, I.; Sempionatto, J.R.; Barfidokht, A.; Mishra, R.K.; Campbell, A.S.; Hubble, L.J.; Wang, J. Wearable Bioelectronics: Enzyme-Based Body-Worn Electronic Devices. Accounts Chem. Res. 2018, 51, 2820-2828. [CrossRef] [PubMed]

16. Windmiller, J.R.; Wang, J. Wearable Electrochemical Sensors and Biosensors: A Review. Electroanalysis 2013, 25, 29-46. [CrossRef]

17. Wu, F.; Yu, P.; Mao, L. Bioelectrochemistry for In Vivo Analysis: Interface Engineering toward Implantable Electrochemical Biosensors. Curr. Opin. Electrochem. 2017, 5, 152-157. [CrossRef]

18. Milton, R.D.; Minteer, S.D. Direct Enzymatic Bioelectrocatalysis: Differentiating between Myth and Reality. J. R. Soc. Interface 2017, 14, 20170253. [CrossRef] [PubMed]

19. Karyakin, A.A. Principles of Direct (Mediator Free) Bioelectrocatalysis. Bioelectrochemistry 2012, 88, 70-75. [CrossRef]

20. Prévoteau, A.; Mano, N. Oxygen Reduction on Redox Mediators May Affect Glucose Biosensors based on "Wired" Enzymes. Electrochim. Acta 2012, 68, 128-133. [CrossRef]

21. Matsumoto, R.; Mochizuki, M.; Kano, K.; Ikeda, T. Unusual Response in Mediated Biosensors with an Oxidase/Peroxidase Bienzyme System. Anal. Chem. 2002, 74, 3297-3303. [CrossRef]

22. Lee, H.; Choi, T.K.; Lee, Y.B.; Cho, H.R.; Ghaffari, R.; Wang, L.; Choi, H.J.; Chung, T.D.; Lu, N.; Hyeon, T.; et al. A Graphene-based Electrochemical Device with Thermoresponsive Microneedles for Diabetes Monitoring and Therapy. Nat. Nanotechnol. 2016, 11, 566-572. [CrossRef] [PubMed]

23. Lee, H.; Song, C.; Hong, Y.S.; Kim, M.S.; Cho, H.R.; Kang, T.; Shin, K.; Choi, S.H.; Hyeon, T.; Kim, D.-H. Wearable/Disposable Sweat-Based Glucose Monitoring Device with Multistage Transdermal Drug Delivery Module. Sci. Adv. 2017, 3, e1601314. [CrossRef] [PubMed]

24. Strakosas, X.; Selberg, J.; Pansodtee, P.; Yonas, N.; Manapongpun, P.; Teodorescu, M.; Rolandi, M. A Non-Enzymatic Glucose Sensor Enabled by Bioelectronic pH Control. Sci. Rep. 2019, 9, 10844. [CrossRef] [PubMed]

25. Nery, E.W.; Kundys, M.; Jeleń, P.S.; Jönsson-Niedziółka, M. Electrochemical Glucose Sensing: Is There Still Room for Improvement? Anal. Chem. 2016, 88, 11271-11282. [CrossRef] [PubMed]

26. Müsse, A.; La Malfa, F.; Brunetti, V.; Rizzi, F.; De Vittorio, M. Flexible Enzymatic Glucose Electrochemical Sensor Based on Polystyrene-Gold Electrodes. Micromachines 2021, 12, 805. [CrossRef]

27. Moyer, J.; Wilson, D.; Finkelshtein, I.; Wong, B.; Potts, R. Correlation Between Sweat Glucose and Blood Glucose in Subjects with Diabetes. Diabetes Technol. Ther. 2012, 14, 398-402. [CrossRef]

28. Kim, J.; Campbell, A.S.; Wang, J. Wearable Non-Invasive Epidermal Glucose Sensors: A Review. Talanta 2018, 177, 163-170. [CrossRef]

29. Klous, L.; de Ruiter, C.J.; Scherrer, S.; Gerrett, N.; Daanen, H.A.M. The (In)Dependency of Blood and Sweat Sodium, Chloride, Potassium, Ammonia, Lactate and Glucose Concentrations during Submaximal Exercise. Graefe's Arch. Clin. Exp. Ophthalmol. 2020, 121, 803-816. [CrossRef]

30. Falk, M.; Andoralov, V.; Silow, M.; Toscano, M.D.; Shleev, S. Miniature Biofuel Cell as a Potential Power Source for Glucose-Sensing Contact Lenses. Anal. Chem. 2013, 85, 6342-6348. [CrossRef]

31. Rahman, M.; Ahammad, A.J.S.; Jin, J.-H.; Ahn, S.J.; Lee, J.-J. A Comprehensive Review of Glucose Biosensors Based on Nanostructured Metal-Oxides. Sensors 2010, 10, 4855-4886. [CrossRef]

32. Thatikayala, D.; Ponnamma, D.; Sadasivuni, K.K.; Cabibihan, J.J.; Al-Ali, A.K.; Malik, R.A.; Min, B. Progress of Advanced Nanomaterials in the Non-Enzymatic Electrochemical Sensing of Glucose and $\mathrm{H}_{2} \mathrm{O}_{2}$. Biosensors 2020, 10, 151. [CrossRef] [PubMed]

33. Yuan, J.H.; Wang, K.; Xia, X.H. Highly Ordered Platinum-Nanotubule Arrays for Amperometric Glucose Sensing. Adv. Funct. Mater. 2005, 15, 803-809. [CrossRef]

34. Gong, X.; Gu, Y.; Zhang, F.; Liu, Z.; Li, Y.; Chen, G.; Wang, B. High-Performance Non-Enzymatic Glucose Sensors Based on CoNiCu Alloy Nanotubes Arrays Prepared by Electrodeposition. Front. Mater. 2019, 6. [CrossRef]

35. Hoshino, T.; Sekiguchi, S.-I.; Muguruma, H. Amperometric Biosensor Based on Multilayer Containing Carbon Nanotube, PlasmaPolymerized Film, Electron Transfer Mediator Phenothiazine, and Glucose Dehydrogenase. Bioelectrochemistry 2012, 84, 1-5. [CrossRef] [PubMed]

36. Xia, H.-Q.; Tang, H.; Zhou, B.; Li, Y.; Zhang, X.; Shi, Z.; Deng, L.; Song, R.; Li, L.; Zhang, Z.; et al. Mediator-Free ElectronTransfer on Patternable Hierarchical Meso/Macro Porous Bienzyme Interface for Highly-Sensitive Sweat Glucose and Surface Electromyography Monitoring. Sens. Actuators B Chem. 2020, 312, 127962. [CrossRef]

37. Liu, Q.; Liu, Y.; Wu, F.; Cao, X.; Li, Z.; Alharbi, M.; Abbas, A.N.; Amer, M.R.; Zhou, C. Highly Sensitive and Wearable In ${ }_{2} \mathrm{O}_{3}$ Nanoribbon Transistor Biosensors with Integrated On-Chip Gate for Glucose Monitoring in Body Fluids. ACS Nano 2018, 12, 1170-1178. [CrossRef] [PubMed]

38. Liu, X.; Huang, D.; Lai, C.; Qin, L.; Zeng, G.; Xu, P.; Li, B.; Yi, H.; Zhang, M. Peroxidase-Like Activity of Smart Nanomaterials and Their Advanced Application in Colorimetric Glucose Biosensors. Small 2019, 15, e1900133. [CrossRef] [PubMed]

39. Zhang, X.; Gu, A.; Wang, G.; Huang, Y.; Ji, H.; Fang, B. Porous Cu-NiO Modified Glass Carbon Electrode Enhanced Nonenzymatic Glucose Electrochemical Sensors. Analyst 2011, 136, 5175-5180. [CrossRef] 
40. Tong, C.V.; Yow, H.Y.; Noor, N.M.; Hussein, Z. Diabetes Emergencies around Ramadan Study (DEARS)—A Multi-Center Study of Diabetes Emergencies Admitted before, during and after Ramadan in Malaysia. Diabetes Res. Clin. Pr. 2021, 175, 108854. [CrossRef]

41. Elhadd, T.; Bashir, M.; Baager, K.A.; Ali, H.A.; Almohannadi, D.H.; Dabbous, Z.; Malik, R.A.; Abou-Samra, A.-B. Mitigation of Hypoglycemia During Ramadan Using the Flash Glucose Monitoring System Following Dose Adjustment of Insulin and Sulphonylurea in Patients Taking Multiple Glucose-Lowering Therapies (The PROFAST-IT Study). Diabetes Res. Clin. Pr. 2021, 172, 108589. [CrossRef]

42. Mehrotra, P. Biosensors and their Applications-A Review. J. Oral Biol. Craniofacial Res. 2016, 6, 153-159. [CrossRef] [PubMed]

43. Chung, J.W.; So, C.-F.; Choi, K.-S.; Wong, T.K. Recent Advances in Noninvasive Glucose Monitoring. Med. Devices Évid. Res. 2012, 5, 45-52. [CrossRef] [PubMed]

44. Hashemizadeh, S.A.; Biglari, M. Cu:Ni Bimetallic Nanoparticles: Facile Synthesis, Characterization and its Application in Photodegradation of Organic Dyes. J. Mater. Sci. Mater. Electron. 2018, 29, 13025-13031. [CrossRef]

45. Hassan, M.; Vyas, C.; Grieve, B.; Bartolo, P. Recent Advances in Enzymatic and Non-Enzymatic Electrochemical Glucose Sensing. Sensors 2021, 21, 4672. [CrossRef] [PubMed]

46. Şavk, A.; Aydın, H.; Cellat, K.; Şen, F. A Novel High Performance Non-Enzymatic Electrochemical Glucose Biosensor based on Activated Carbon-Supported Pt-Ni Nanocomposite. J. Mol. Liq. 2019, 300, 112355. [CrossRef]

47. Gao, X.; Du, X.; Liu, D.; Gao, H.; Wang, P.; Yang, J. Core-Shell Gold-Nickel Nanostructures as Highly Selective and Stable Nonenzymatic Glucose Sensor for Fermentation Process. Sci. Rep. 2020, 10, 1365. [CrossRef] [PubMed]

48. Druska, P.; Strehblow, H.-H.; Golledge, S. A Surface Analytical Examination of Passive Layers on CuNi Alloys: Part I. Alkaline Solution. Corros. Sci. 1996, 38, 835-851. [CrossRef]

49. Luo, P.; Prabhu, S.V.; Baldwin, R.P. Constant Potential Amperometric Detection at a Copper-Based Electrode: Electrode Formation and Operation. Anal. Chem. 1990, 62, 752-755. [CrossRef]

50. Mathew, M.; Sandhyarani, N. A Highly Sensitive Electrochemical Glucose Sensor Structuring with Nickel Hydroxide and Enzyme Glucose Oxidase. Electrochim. Acta 2013, 108, 274-280. [CrossRef]

51. Ding, R.; Liu, J.; Jiang, J.; Wu, F.; Zhu, J.; Huang, X. Tailored Ni-Cu Alloy Hierarchical Porous Nanowire as a Potential Efficient Catalyst for DMFCs. Catal. Sci. Technol. 2011, 1, 1406-1411. [CrossRef]

52. Jafarian, M.; Forouzandeh, F.; Danaee, I.; Gobal, F.; Mahjani, M.G. Electrocatalytic Oxidation of Glucose on Ni and NiCu Alloy Modified Glassy Carbon Electrode. J. Solid State Electrochem. 2008, 13, 1171-1179. [CrossRef]

53. Bankar, S.B.; Bule, M.V.; Singhal, R.S.; Ananthanarayan, L. Glucose Oxidase-An Overview. Biotechnol. Adv. 2009, 27, 489-501. [CrossRef]

54. Cheshideh, H.; Nasirpouri, F. Cyclic Voltammetry Deposition of Nickel Nanoparticles on Tio2 Nanotubes and their Enhanced Properties for Electro-Oxidation of Methanol. J. Electroanal. Chem. 2017, 797, 121-133. [CrossRef]

55. Pan, W.; Zheng, Z.; Wu, X.; Gao, J.; Liu, Y.; Yuan, Q.; Gan, W. Facile synthesis of 2D/3D hierarchical NiCu bimetallic MOF for non-enzymatic glucose sensor. Microchem. J. 2021, 170, 106652. [CrossRef]

56. Yi, W.; Liu, J.; Chen, H.; Gao, Y.; Li, H. Copper/Nickel Nanoparticle Decorated Carbon Nanotubes for Nonenzymatic Glucose Biosensor. J. Solid State Electrochem. 2015, 19, 1511-1521. [CrossRef]

57. Njoko, N.; Louzada, M.; Britton, J.; Khene, S.; Nyokong, T.; Mashazi, P. Bioelectrocatalysis and Surface Analysis of Gold Coated with Nickel Oxide/Hydroxide and Glucose Oxidase towards Detection of Glucose. Colloids Surf. B Biointerfaces 2020, $190,110981$. [CrossRef]

58. He, J.; Yang, H.; Zhang, Y.; Yu, J.; Miao, L.; Song, Y.; Wang, L. Smart Nanocomposites of Cu-Hemin Metal-Organic Frameworks for Electrochemical Glucose Biosensing. Sci. Rep. 2016, 6, 36637. [CrossRef]

59. Fang, L.; Liu, B.; Liu, L.; Li, Y.; Huang, K.; Zhang, Q. Direct Electrochemistry of Glucose Oxidase Immobilized on Au NanoparticlesFunctionalized 3D Hierarchically ZnO Nanostructures and its Application to Bioelectrochemical Glucose Sensor. Sens. Actuators B Chem. 2016, 222, 1096-1102. [CrossRef]

60. Li, Z.; Gao, F.; Gu, Z. Vertically aligned Pt Nanowire Array/Au Nanoparticle Hybrid Structure as Highly Sensitive Amperometric Biosensors. Sens. Actuators B Chem. 2017, 243, 1092-1101. [CrossRef]

61. Li, J.; Liu, Y.; Tang, X.; Xu, L.; Min, L.; Xue, Y.; Hu, X.; Yang, Z. Multiwalled Carbon Nanotubes Coated with Cobalt(II) Sulfide Nanoparticles for Electrochemical Sensing of Glucose via Direct Electron Transfer to Glucose Oxidase. Microchim. Acta 2020, 187, 80. [CrossRef] 